\title{
Fiscal Sustainability: Responsiveness in Times of Crisis: A Review of Sub-National Governments in Mexico*
}

\author{
Alain Dimitrius Izquierdo Reyes, Juan Diego Omar Martínez Delgado \\ University of Guadalajara, Guadalajara, Mexico \\ University of Panamericana, Guadalajara, Mexico
}

\begin{abstract}
This paper attends to the issue of sustainability and responsiveness administration under the following premise: Appropriate management of public finances is essential to comply with the provision of public goods and services, which results in the priority agenda of public policies driving governments, however, this may be at risk agenda by two main factors: (1) management of public finances; and (2) external shock: recessions and financial crisis. Consequently, it must generate elements to enhance the responsiveness of governments, as is the implementation of instruments of fiscal sustainability in the public finances that allows reduce the impact of the external economic shocks, the debt overhang and inhibit acts of corruption endanger public services. In this sense, the document in the first part seeks to illustrate the Mexican case, in an approach from the review of legislation by type of sub-national and statistics of public debt and fiscal sustainability indicators. In a second stage is to link the responsiveness of the variable public spending on public services and their relation to the year of recession. Finally, the results will be analyzed to issue policy recommendations.
\end{abstract}

Keywords: sub-national government, fiscal sustainability, public debt, public policies, México

The government's agenda is the platform through which political parties offer goods and services to citizens-voters, and these in turn elect the political market the best selection that is related to your preferences. Once elected arise, leaders must translate those campaign promises into action, into concrete policies (World Bank, 2010). Therefore, it is highly significant to identify financial mechanisms that will translate into public policy platform of government and how those platforms retain the objectives or lost in the programs contained in the national budget; besides, it is important to analyze that the budgets are reduced to levels of ineffectiveness in times of crisis.

Then, it becomes relevant funding programs and the administration of public finances and public resources for different levels or spheres of government in which a nation is divided. For Valle and Galindo (2010), the literature indicates that the financial difficulties posed by certain sub-national entities, originate in the problems

\footnotetext{
* This paper was presented at the International Congress of Public Policies on July 1-4, 2015, in Milan, Italy. And this paper is funded by Ph.D. fiscal studies at University of Guadalajara and National Council of Science and Technology from México (CONACYT).

Corresponding author: Alain Dimitrius Izquierdo Reyes, Ph.D. candidate, economist, researcher, University of Guadalajara, professor, University of Panamericana; research fields: fiscal sustainability, public debt, fiscal policy, and public policy. E-mail: alainizquierdor@gmail.com.

Juan Diego Omar Martínez Delgado, postgraduate in finance, MA in public administration, economist, researcher, and speaker in public finance topics, University of Guadalajara, University of Panamericana; research fields: public finance, fiscal federalism, and public expenditure. E-mail: juandiego.mar@gmail.com.
} 
of common resources (common pool resources) as well as budget constraints and weak moral hazard among levels of government.

\section{Context}

The country of Mexico (United Mexican States), is a democratic, federal, representative republic, structured by a (central) federal government, 31 states (sub-national), a Federal District (Mexico City,) and 2,457 municipalities (localities) in the country. These levels of government must implement policies and programs in a government agenda, financed mainly through public funds, in some cases, public-private and social partnership; although not all levels of government have sufficient fiscal resources to generate optimal public spending on public goods and services. Therefore, in this paper, the behavior of the growth of public debt of governments, as a first approximation to the positive or negative fiscal sustainability analyzes, as appropriate, especially after the crisis of 2009. For example, sub-national and local governments derive their income primarily via tax (taxes, fees, products, and uses, represent on average $6 \%$ of the total) and no tax (transfers or funds provided by the central government, average $91 \%$ of the total), which also increased by revenues gained by contracting debt in various forms.

By counterpart, public spending by governments, continues in some cases, an incompatible inertia level of public revenues, and also, for some dynamic well above the population growth; as well as the economy, especially in times of crisis. This means that public spending in Mexico is growing faster than the growth rate of the economy, which in theory ought to be the natural source for the basis of income, so that a higher level of activities in the economy higher tax collection possibilities, however, not the case for some.

Meanwhile, the fiscal agreement in Mexico is based on a revenue sharing system shares that transfers to sub-national governments, a share of the revenues collected by the central government, contemplating part of oil revenues, in exchange for having renounced the collection of local taxes on income and sales. In this context, fiscal autonomy has its advantages and disadvantages that allows levels of government whether or not to tax collection capacity, according to the transfer system ever designed, whether horizontal or vertical, as well as the design of tax powers of each government level and the corresponding obligations to deliver public goods and services to citizens on their territory (R. Musgrave \& P. Musgrave, 1989; Rosen, 2000; Stiglitz, 2000).

For the Mexican case, fiscal decentralization has caused, or may cause certain problems, such as fiscal discipline at the sub-national governments (Hernandez, 2002), the probability that a higher level of government to rescue them if they come into conflict financial, causing the paradox of tragedy of the commons (Hardin, 1968).

In particular, this paper is a review of sub-national governments in relation to expenditure requirements and debt levels; and legislation is also described in terms of sub-national debt. Subsequently, financial discipline is reviewed and described generally anti-crisis plans implemented during the last global financial crisis.

\section{Public Debt and Fiscal Sustainability}

From the technical point of view, excessive public debt can be reflected until the financial capacity allows incur debt, either through increased income support or transfers collateral or refinancing to enable the liberalization of resources in the short term. In this sense, the reason for acquiring more debt is in accordance with the needs of public and public sector financial policies, economic solvency to meet the loan and the current regulation. 
However, there is also the explanation from the point of view of political economy, as discussed in recent years. The Inter-American Development Bank (IADB) (2007) has developed a series of reflections to explain the excessive borrowing of sub-national governments in the countries in Latin America in recent decades. The reflection of the basic model of public debt, which is based on a benevolent government that uses debt to finance capital accumulation or natural and financial disasters or economic fluctuations, but in fact, the decisions on debt and fiscal policy are made by politicians who have other plans (next election and the interests of their own jurisdictions).

Therefore, these considerations are important factors when making decisions, as the basic model of why governments go into debt and what determines debt levels and evolution over time is explained.

The main explanations are based on the political economy problem that arises in relation to government debt, amount, use, destination, time, and controlling it, among other factors. Therefore, the following positions are described (see Figure 1):
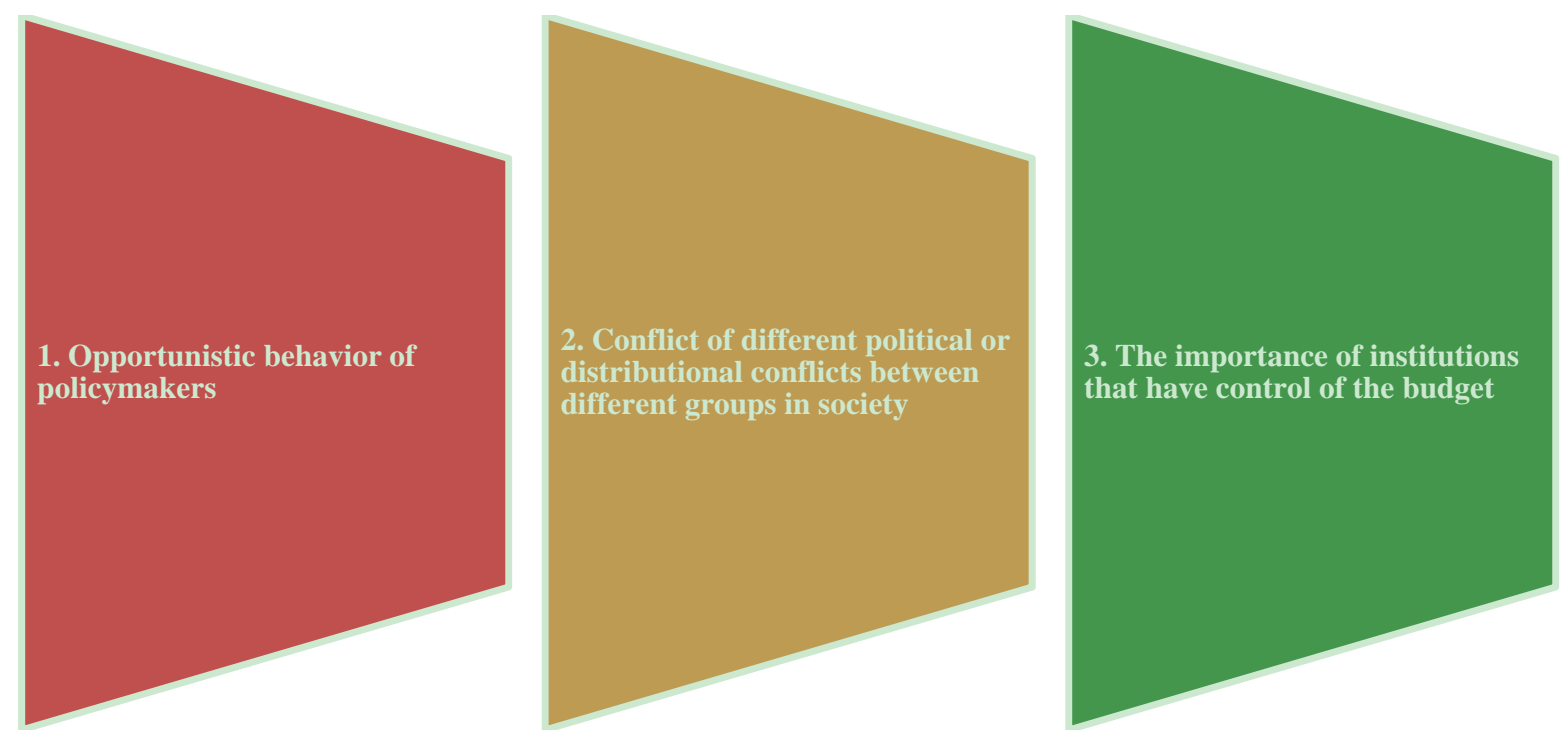

Figure 1. Explanations of political economy in three major theories about excessive public debt and fiscal sustainability. Source: prepared by IADB information.

Regarding the opportunistic behavior of policymakers, Buchanan and Wagner (1977) indicated that voters give their support to the authorities with budget and public resources, thus are more likely to public spending to fulfill them. Similarly, Rogoff and Sibert (1988) mentioned a politician running more government programs is more preferably with the electorate, hence, they are high for policy incentives to incur a deficit.

Meanwhile, in the case of evidence of a relationship between budget transparency and fiscal outcomes (Alt, Lassen, \& Rose, 2006), explained in a sample of developing and developed countries, there is a strong negative correlation between accountability and budget deficits.

The above point is related to the provisions for Schuknecht (1994), where related accountability and deficits in developing countries with increases in public spending before the election. Tabellini and Alesina (1990) abounded in the opportunistic behavior of policymakers, where a political will find attractive incurs a deficit for maximizing the benefits to the electorate and provide those public goods that have higher preferences. In turn, Scartascini, Spiller, Stein, and Tommasi (2011) mentioned that political disputes over the distribution of tax funds available and the state's inability to adjust the fiscal accounts are considered as the causes of 
default and the crisis in Argentina during the period 2001-2002.

Then, the appropriate or ideal public sector size can distort when politicians make decisions, especially governments with low fiscal solvency, for example, expanding social programs, bureaucratic structure, public works, among others, bordering the indebtedness or deficits. In the case of budgetary institutions for debt accumulation is important, as it will depend on the constraints that policymakers face when deciding on the budget, as such, Alesina, Hausmann, Hommes, and Stein (1999) noted that the main rules to restrict the decision-making of politicians are numerical targets, rules of procedure, and rules of transparency.

(1) Rules of procedure are used to establish the duties and rights of the policymakers involved in negotiations on the budget;

(2) Restrictions on the procedures can be divided into those that prevent the legislature to increase the total amount of expense and preventing changes in the levels of deficit;

(3) Rules "hierarchical” and "collegial”;

(4) Hierarchical: often concentrate budgetary power in the finance ministry, within the cabinet, and in the executive branch instead of the legislative branch;

(5) Collegiate: Are those that allow more representation of different interests in the budgetary process but risk generating overspending problems.

Similarly, another key player is the courts of justice, IADB (2007) evidenced of judicial activism in eight Latin American countries affects the formulation of fiscal policies in Latin America, and the results support the hypothesis that judicial activism is correlated with a higher deficit.

In a major effort to deepen the role of fiscal institutions, Garcia (2012) noted that well-designed fiscal rules can help further enhance the stabilizing role of fiscal policies and increase the capacity of the authorities to counter exogenous shocks. However, they should avoid a pro-cyclical bias and care application, suspension or adaptations of fiscal measures.

Garcia finally notes that the tax rules based on structural budget balances, or adjusted for the economic cycle can contribute simultaneously to reduce or eliminate the pro-cyclical bias of fiscal policy, strengthen fiscal sustainability and strengthen the credibility of macroeconomic policies in general. However, for a rule of this nature to be effective, credible, and sustainable over time, given its technical complexity, it depends on two key areas: political economy (political stability and consensus) and institutional, economic, and technical preconditions.

From a macroeconomic point of view, the problem of fiscal sustainability for Cespedes (2011) can be minimized by considering certain policy measures to address the situation:

(1) Clear sunset clauses in policies of economic intervention or debt according to the new economic situation and measures to eliminate economic distortions;

(2) Increase the range of automatic stabilizers which, by their nature, are anti-cyclical;

(3) Commit to implement future defined corrective action and set a specific date or contingently as well as consider a smooth process of elimination to avoid sudden drops;

(4) Establish more robust medium-term fiscal frameworks and strengthen fiscal governance;

(5) Improve procedures to ensure that spending increased outlays on infrastructure and public works is correctly aimed at raising potential growth in the long term.

In conclusion, the Secretary of Finance and Public Credit (2011), noted that there is systematic risk when public debt is used to meet the commitments of government and there is no economic growth in line with the 
levels of indebtedness, which raises the likelihood of facing financial insolvency scenarios. Furthermore, it is necessary to consider regulatory elements that inhibit the irrational behavior of decision makers through institutional mechanisms that encourage proper management of public debt.

About fiscal sustainability, the Government Accounting Standards Board (GASB) (2009) noted that fiscal sustainability is the ability and willingness of a government to generate the income needed to meet both the current service commitments and financial obligations in expiration. Meanwhile, Chapman (2008) defined as the ability to over time, to ensure continued service delivery and levels of capital required public demand. However, Ward and Dadayan (2009) indicated that it is simply the ability of a government to balance income and expenditure in the long term.

At the sub-national level, Zhao (2012) defined fiscal sustainability as the long-term ability of state and local governments to provide public services demand and willing to have a balance in revenues and expenditures of the public sector over time. Meanwhile, Coronado (2009) defined sustainability of public finances in sub-national governments, the ability to generate or raise sufficient resources to meet its expenses permanently, and honor the debt service, without incurring arrears, renegotiate debt or make a significant fiscal adjustment. Such sustainability of public finances must contain two components: the ability to generate sufficient resources (fiscal sustainability) and a level of debt that does not generate payment problems (debt sustainability).

Other mechanisms that are intended to generate fiscal sustainability, especially in times of crisis, are the stabilization funds, which can be defined as leveling mechanisms in public budgets, used by governments to deal with economic cycles and work through the provision of resources originating from income surplus budgets covered mainly raw materials such as oil, copper, among others. The definition and criteria stabilization funds are instituted in laws and budgetary rules that determine the mechanics to be used, especially in times of recession or economic slowdown, to meet contingencies and to finance long-term policies (pension, health, and education).

However, E. Borensztein, E. Levy, and U. Panizza (2007, p. 60) mentioned that the funds can be easily expropriated by politicians if no suitable control schemes (strict regulatory framework), causing not have incentives to respect and promote pro-cyclical policies, therefore, they relate that these are political failures (political economy and institutional failures) rather than market failures own. Therefore, in conclusion, framing measures of fiscal sustainability actions they are grouped in tax rules, which are budgetary, rules establishing criteria for optimal management of fiscal responsibility.

\section{Public Finance in Mexico}

In the Mexican federal system, there are three levels of government: federal (central), state (sub-national), and municipal (local). Regarding revenue collection, most are charged by the central government, which collects a tax-for the intergovernmental agreement the two main taxes: value added tax (VAT) and income tax (individuals and companies) value addition the central government receives the oil extraction rights of the nation.

The sub-national government has its tax powers, supported the lodging tax and payroll tax as well as the possession and purchase of vehicles. As for the (local) municipal governments, they support their own income in property taxes and rights for public entertainment licenses. In addition to the own income levels, state and municipal governments receive transfers from the federation: shares and fund contributions and other funds that 
support regularizable not on average $90 \%$ of public spending. A third source of government funding is coming from the debt, which can only be destined to expenses of public investment, which is defined in the legislation.

In a first phase, in this review of public finances, we can describe the overall federal government spending is at levels below $25 \%$ of the total value of the economy, and even the income is not sufficient to cover the budget, using controlled deficits, approved by congress by $3 \%$ on average (see Figure 2).

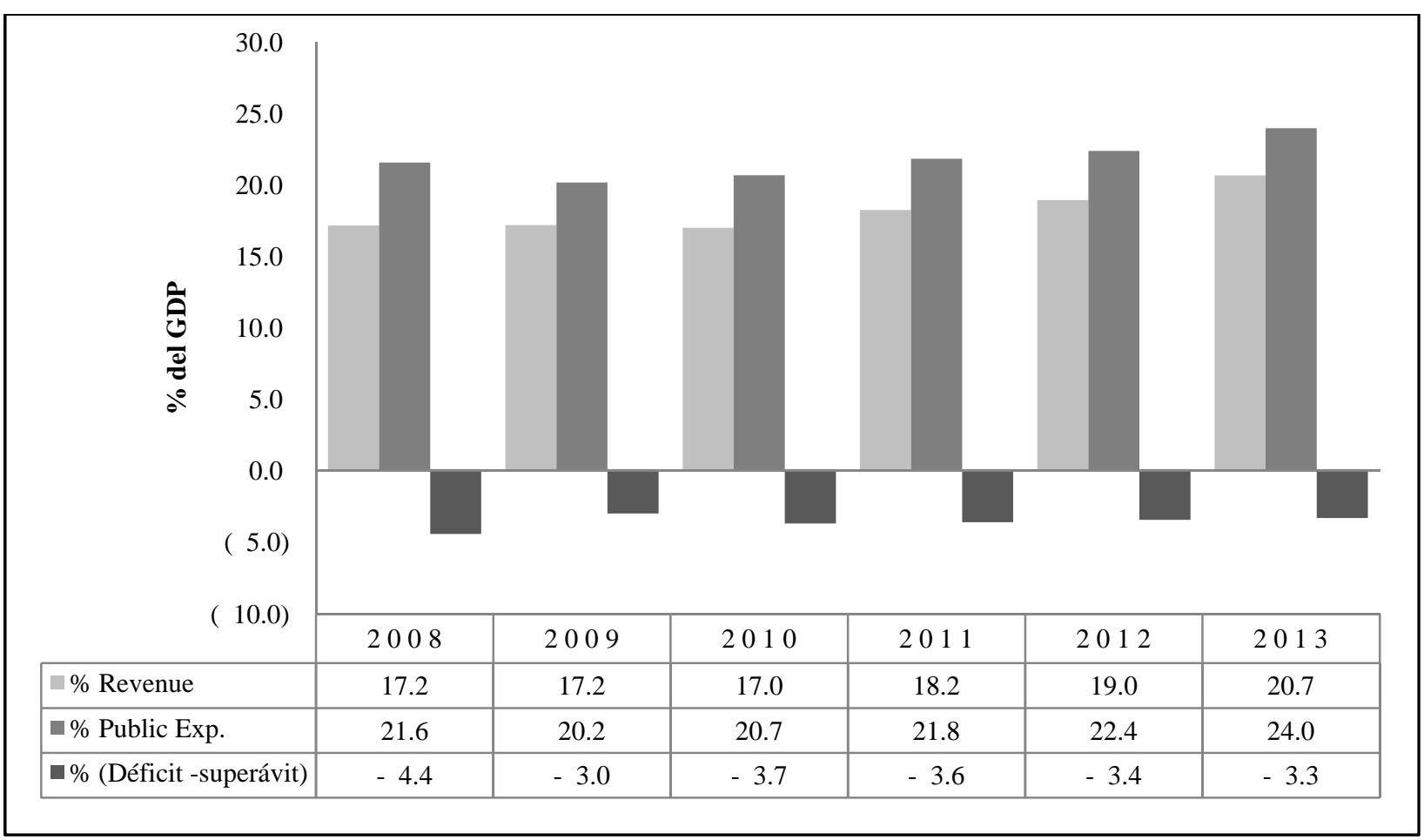

Figure 2. Revenue and expenditures federal government primary deficit or surplus budget (annual \%). Source: prepared with data from National Institute of Statistics (INEGI).

With regard to the tax burden the country is concerned, it has been improving in recent years, but is still below the OECD (Organization for Economic Co-operation and Development) countries and most of Latin America. Besides this load, it generates most only the central government and state and local governments accounted for $1.4 \%$ of the $20.5 \%$ of 2012 , i.e., they generate $7 \%$ of total national tax burden (see Figure 3).

In the case of income of the states in the country, these are a generation of income on average $7.3 \%$, transfers received from the federal government $80.2 \%$, finance (debt) $8.4 \%$, and other resources $4.1 \%$. The performance that has state revenues shows a drop observed between the periods 2000-2002 and 2009-2012 (see Figure 4).

As for the level of public spending, it remains lower growth rates from 2008-2010 and has maintained a slight increase from 2011, but still has weaknesses in expanding the responsiveness of public expenditure in the sub-national governments. The main items of the budget are transfers and supports approximately $40 \%$, wages and salaries $22 \%$, infrastructure and public works with a downward trend and debt service spending upward. Therefore, the responsiveness of expenditure has been weakened by income instability and debt growth (see Figures 5, 6, and 7).

As shown in Figure 7, the crisis brought a contraction in public spending that could not be recovered from the previous rates close to $20 \%$, now rates are found just above $10 \%$. 


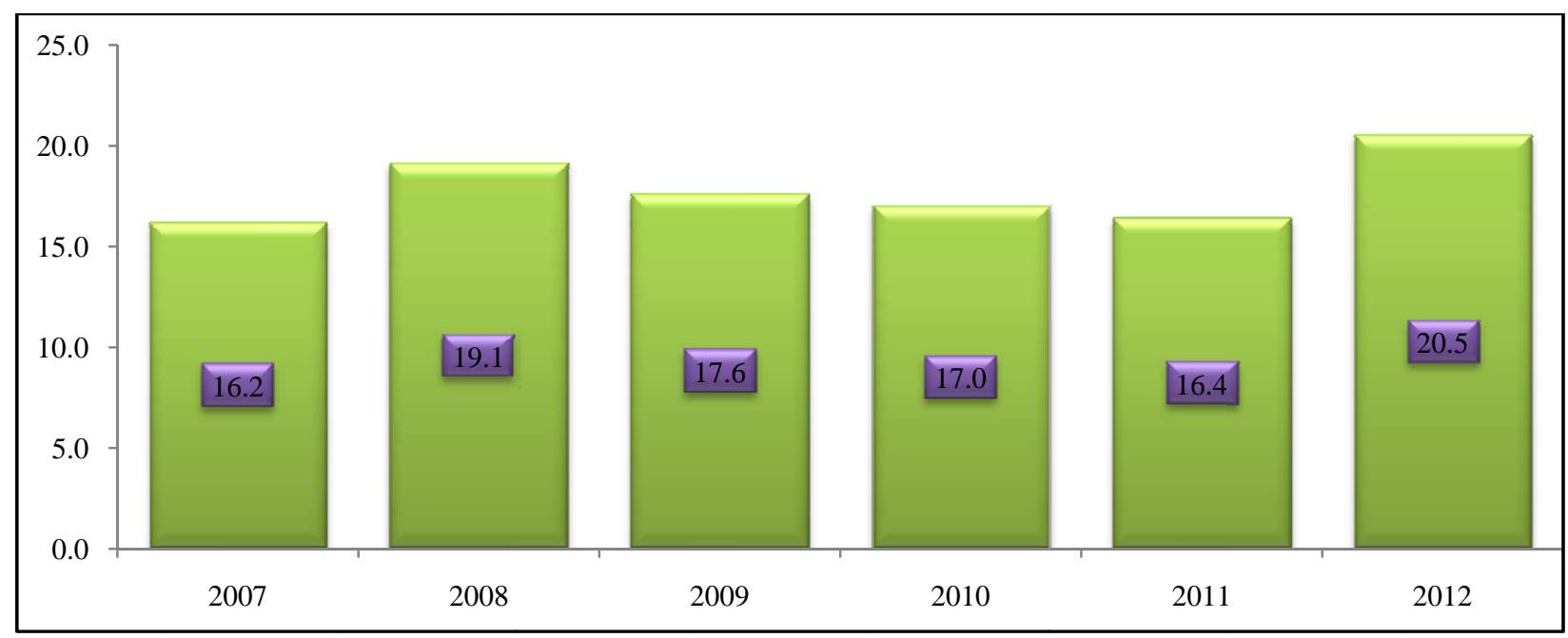

Figure 3. Revenues as GDP (gross domestic product) (annual \%). Source: prepared with data from INEGI.

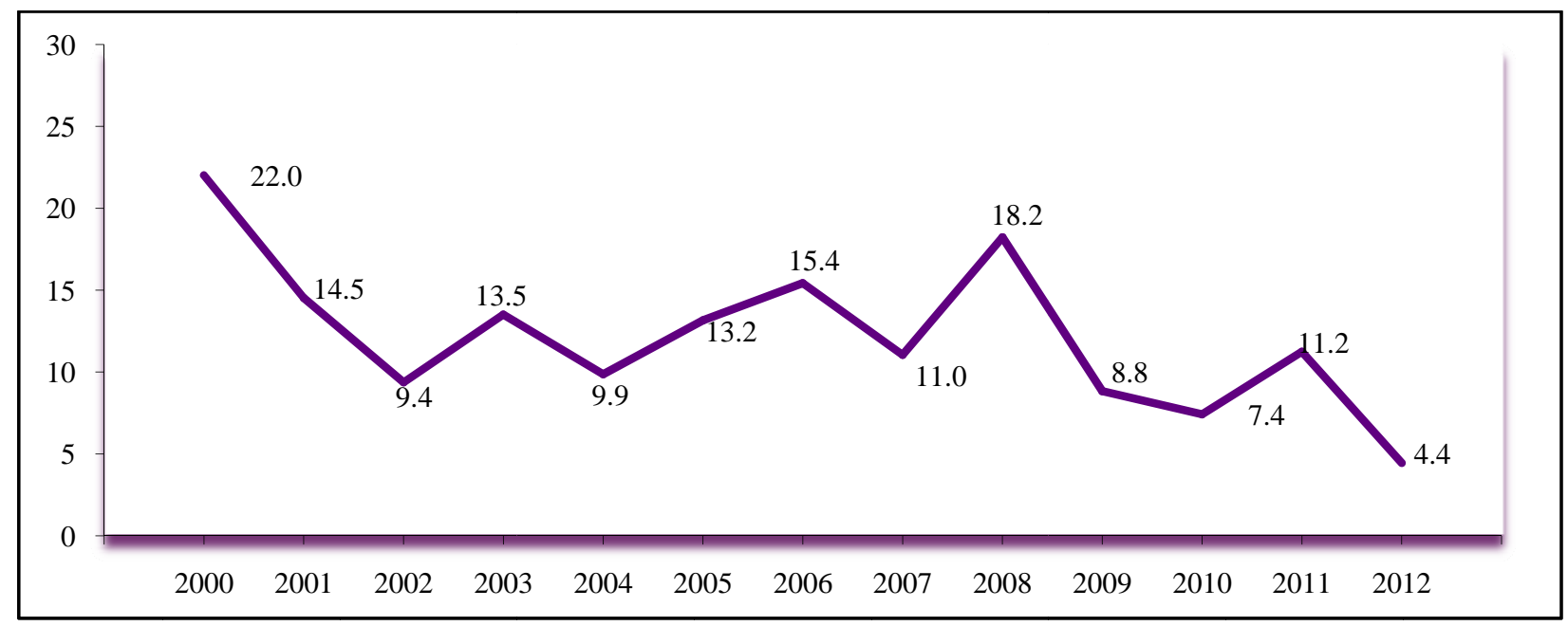

Figure 4. Evolution of state revenue 2000-2012 annual variation (\%). Source: prepared with data from INEGI.

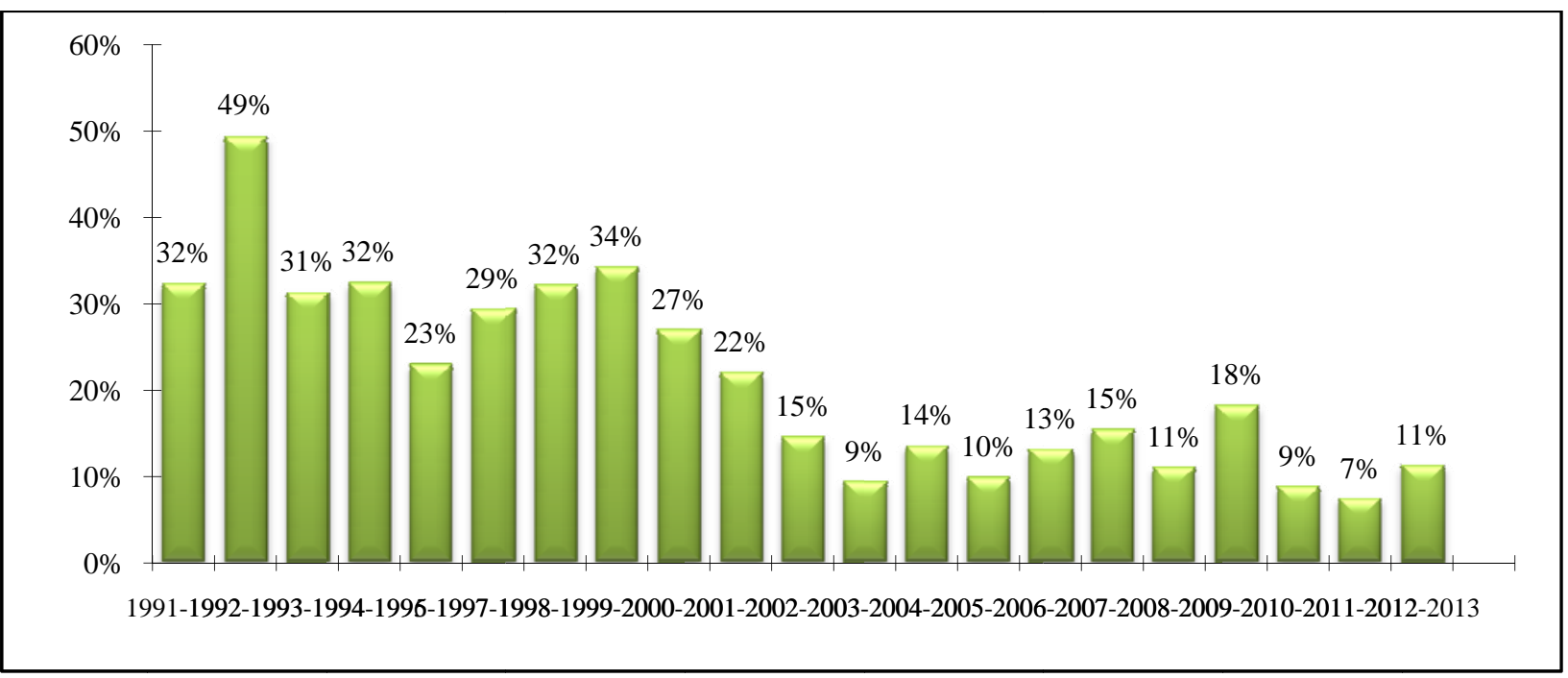

Figure 5. Series sub-national spending rate growth (annual \%). Source: prepared with data from INEGI. 


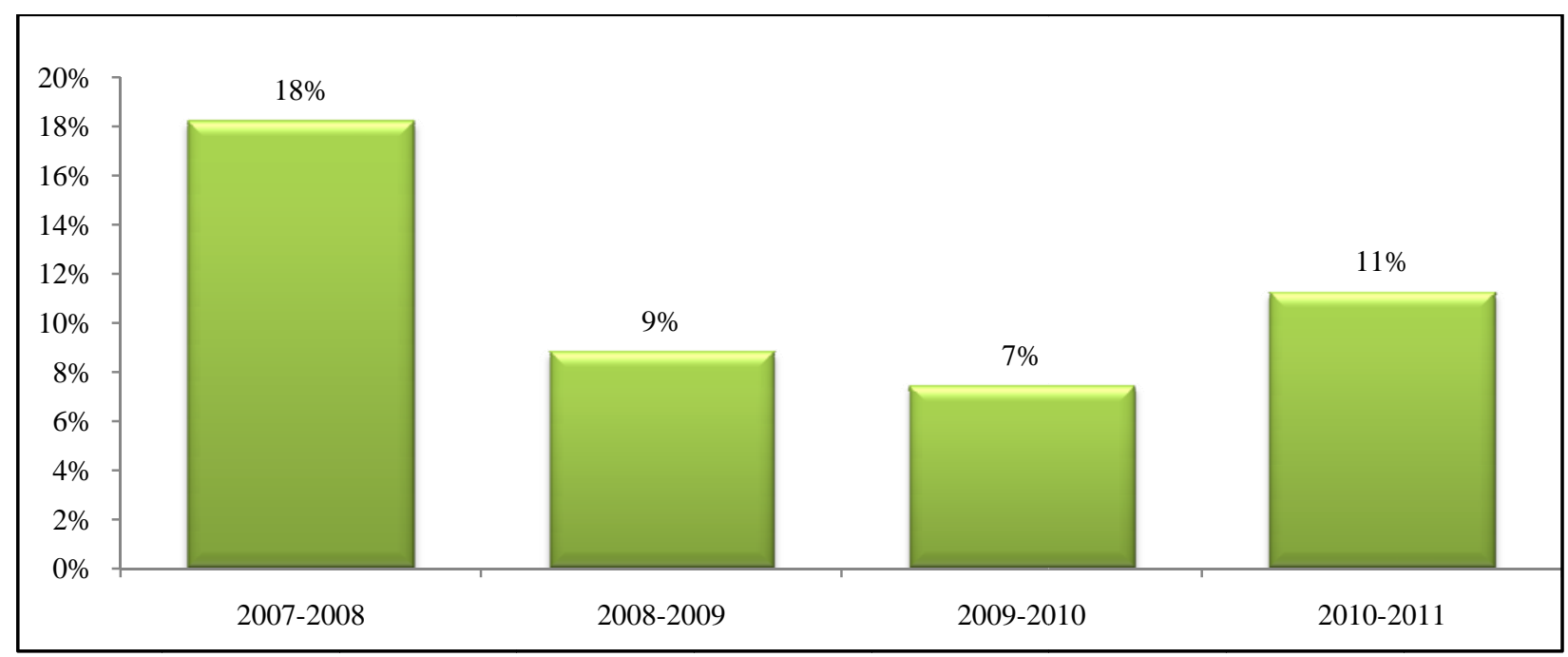

Figure 6. Rate sub-national public spending in the period of financial recession (\%). Source: prepared with data from INEGI.

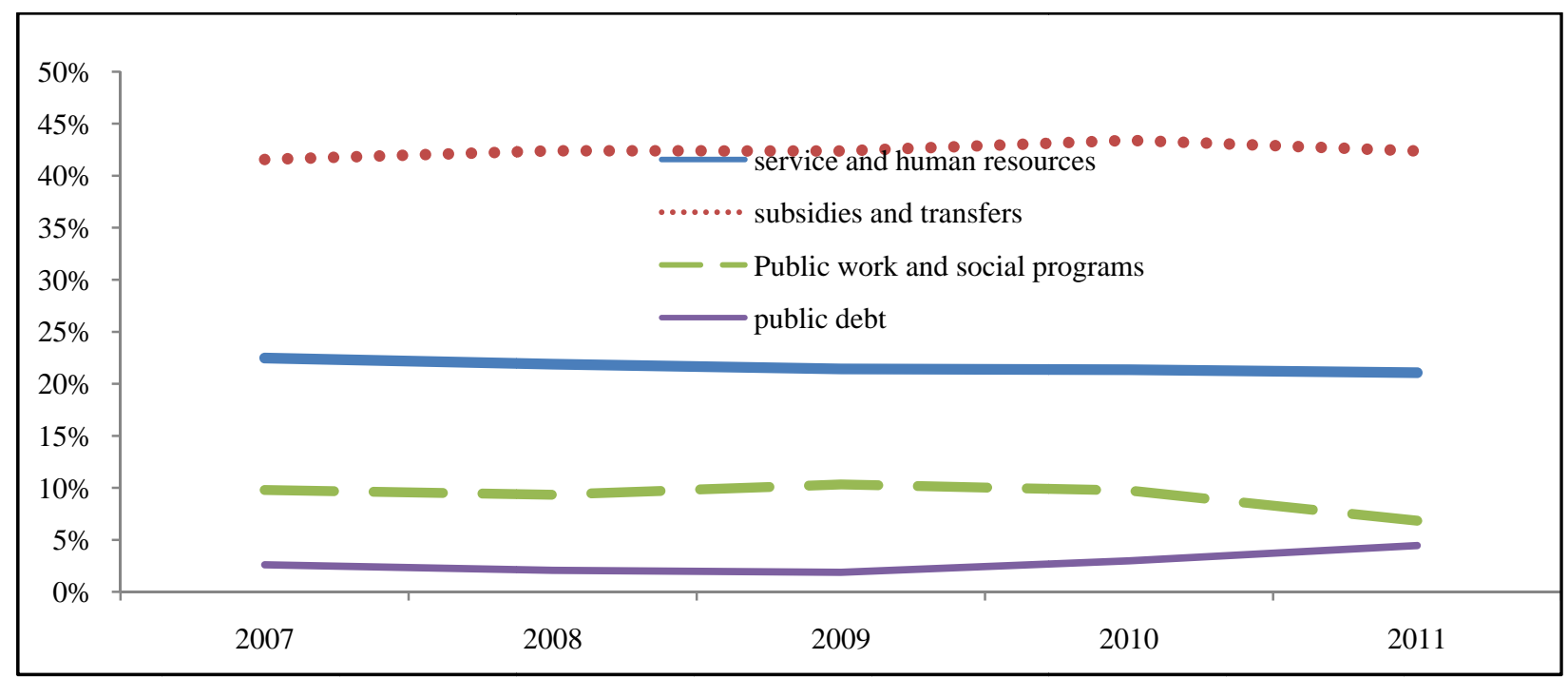

Figure 7. Main items of public expenditure as a percentage of total expenditure (\%). Source: prepared with data from INEGI.

\section{Levels of Public Debt Sustainability in Sub-National Governments of Mexico}

In the particular issue of fiscal sustainability, it is a result of excessive borrowing by governments, which undermines the ability to pay current and future spending, while pressing the finances in the short term which means fewer public goods and services the citizens. It is also important to consider the public pension systems in sub-national governments. In Mexico, they are held in single pillar systems, these being defined benefit, and in few cases are held in sets of two pillars, defined benefit and defined contribution. The "quid" then for governments is to maintain a level of actuarial reserves to sustain financial returns with pensions of the current generation and ensure sustainability of the future generation with contribution percentages that do not obstruct the liquidity of the workers or the government in turn, a challenge nothing less.

Pension systems of sub-national governments are less than a decade to become a problem for local finance, in fact already beginning to be a problem for 15 of the 32 states. Therefore, to add direct debt, the amount of 
contingent liabilities, the sub-national governments grow its unsustainability in some cases, as in many workers' pensions are paid directly from the budget, this is not that they include any amount in its actuarial reserves, or what is called cash deficit. All this puts at risk the sustainability of public debt and finances of sub-national governments.

Consequently, the debt overhang has accelerated in recent years, on average such indebtedness represents approximately 3.1\%. State gross domestic product (SGDP) by the end of 2014, reaching the record, and accelerated since 2009 (see Figure 8).

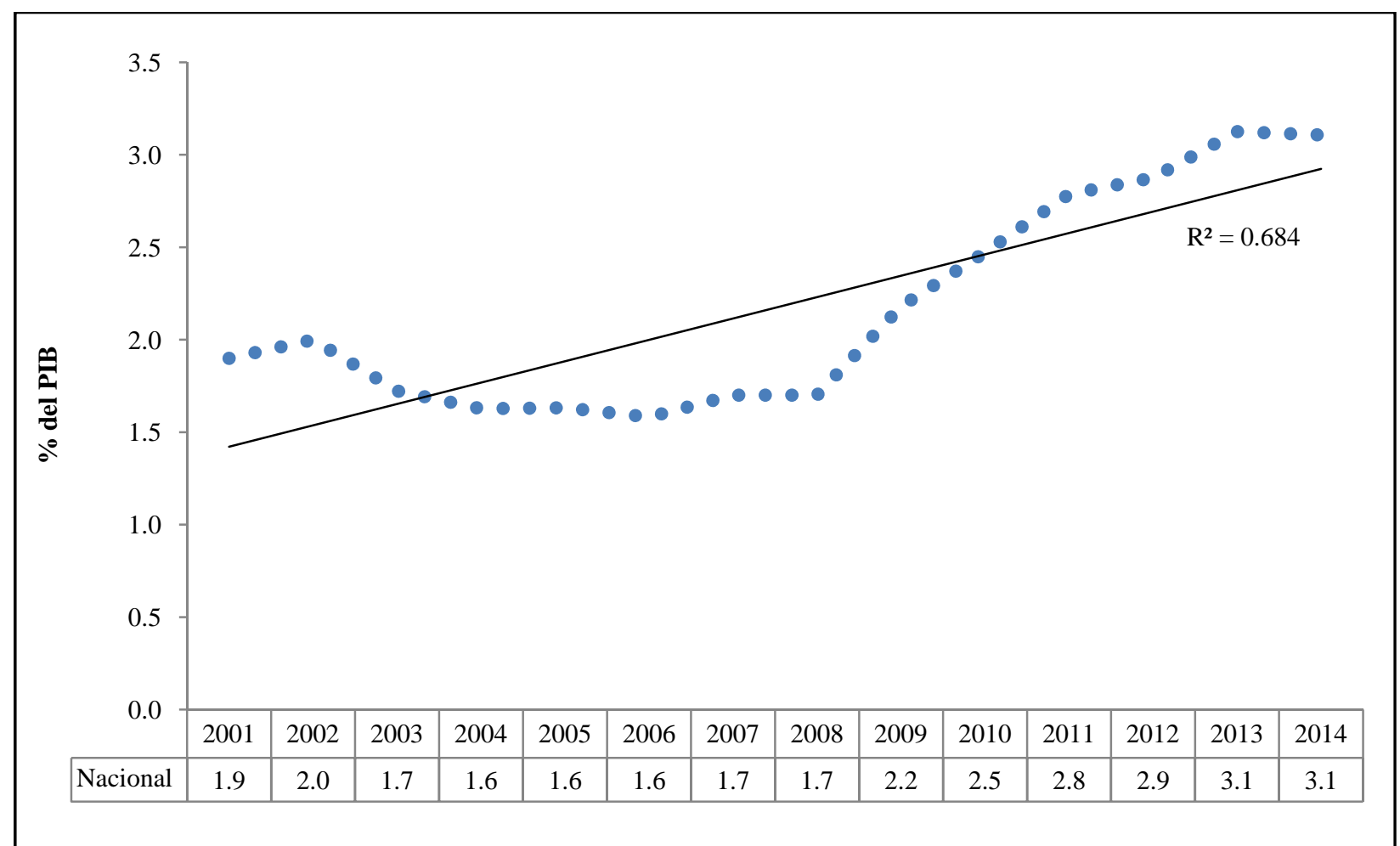

Figure 8. Balance of public debt as a percentage of GDP subnational. Source: prepared with data from INEGI.

Regarding the overall amount of debt of all states is approximately 35 billion dollars, in December 2014, continuing with increasing growth, but at a slower rate between the periods 2009-2011 (see Figure 9).

As for the level of debt as a proportion of the shares, federal contributions (participations) received by sub-national governments, on average these have been increasing since 2008 when the financial crisis hit most of the economies, which results in financial pressure by engaging their income to pay off the debt acquired, therefore, reduced availability of resources for the budget and financing of public policies (see Figure 10).

Sub-national governments in 2009 exceeded the limit could not be reversed and brought consequences for future years. Recently in 2014, the percentage of the committed debt was reduced compared with their federal contributions.

Another relevant indicator is the average term of years to cover loans acquired since 2006 from 8.3 years to currently reach 14.7 years on average needed to pay off the total debt, like show it in Figure 11. 


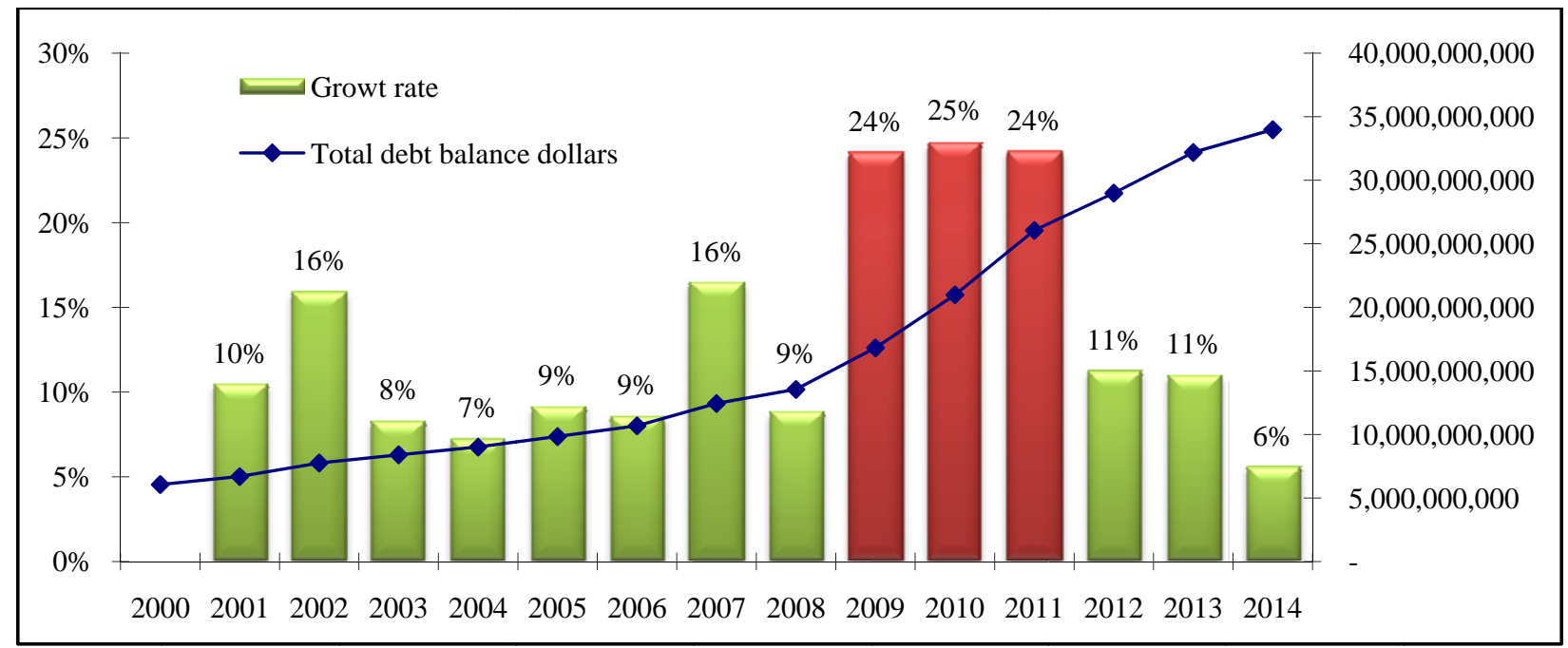

Figure 9. Balance of public debt as a percentage of SGDP (\%). Source: prepared with data from INEGI.

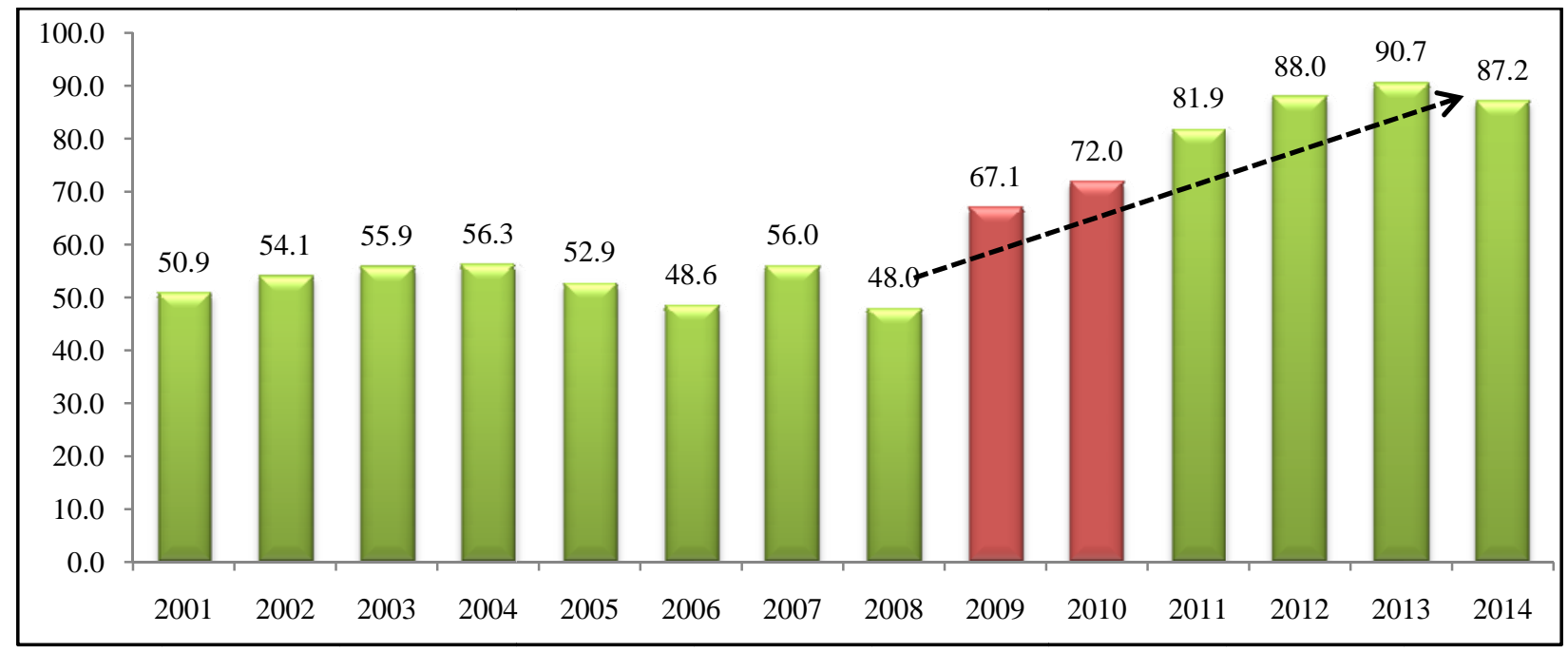

Figure 10. Balance of public debt as a percentage of federal contributions (participations). Source: prepared with data from INEGI.

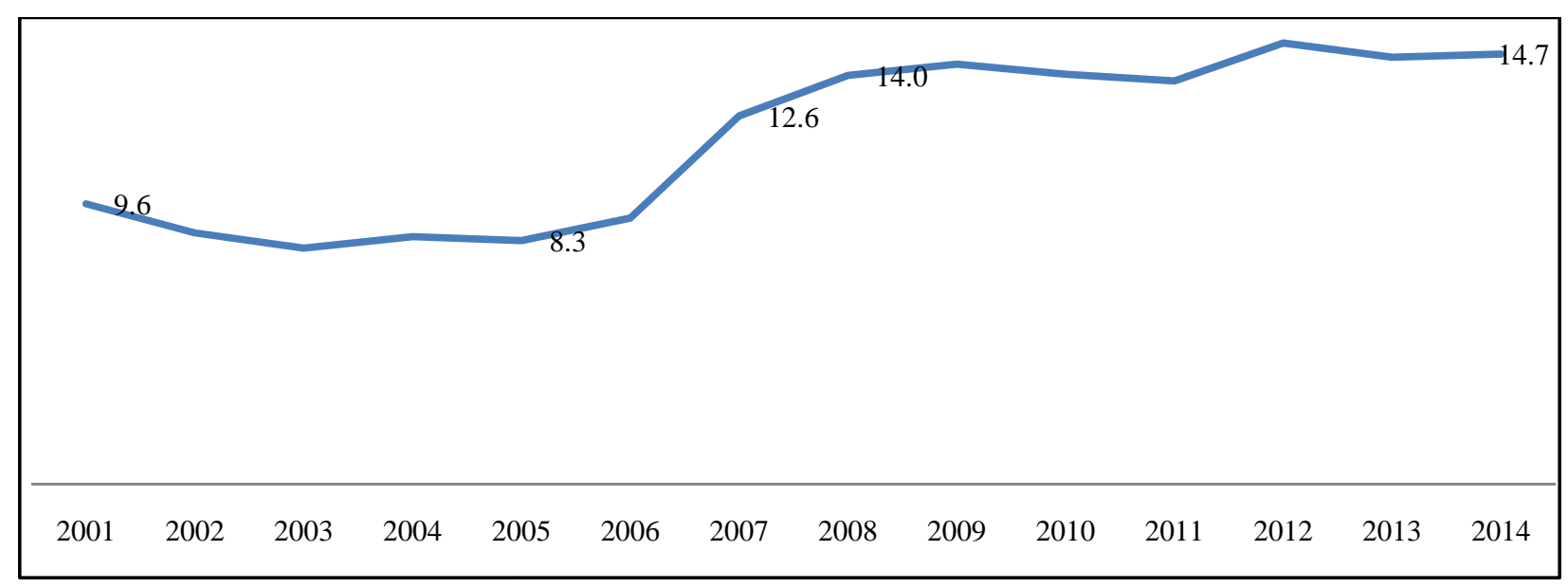

Figure 11. Years averages sub-national time to pay debt. Source: prepared with data from INEGI. 
This is aggravated when external factors like recessions and economic cycles deepen the vulnerability, as occurred in the 2008-2009 financial crisis, leaving serious consequences for national and sub-national economies. For example, tax revenues from oil have fallen and have not recovered their share since 2008, so it was decided to implement tax reforms at the central level in recent years, however, public finances are weak as a result the decline in oil prices, the country is still dependent on natural resources (see Figure 12 and Figure 13).

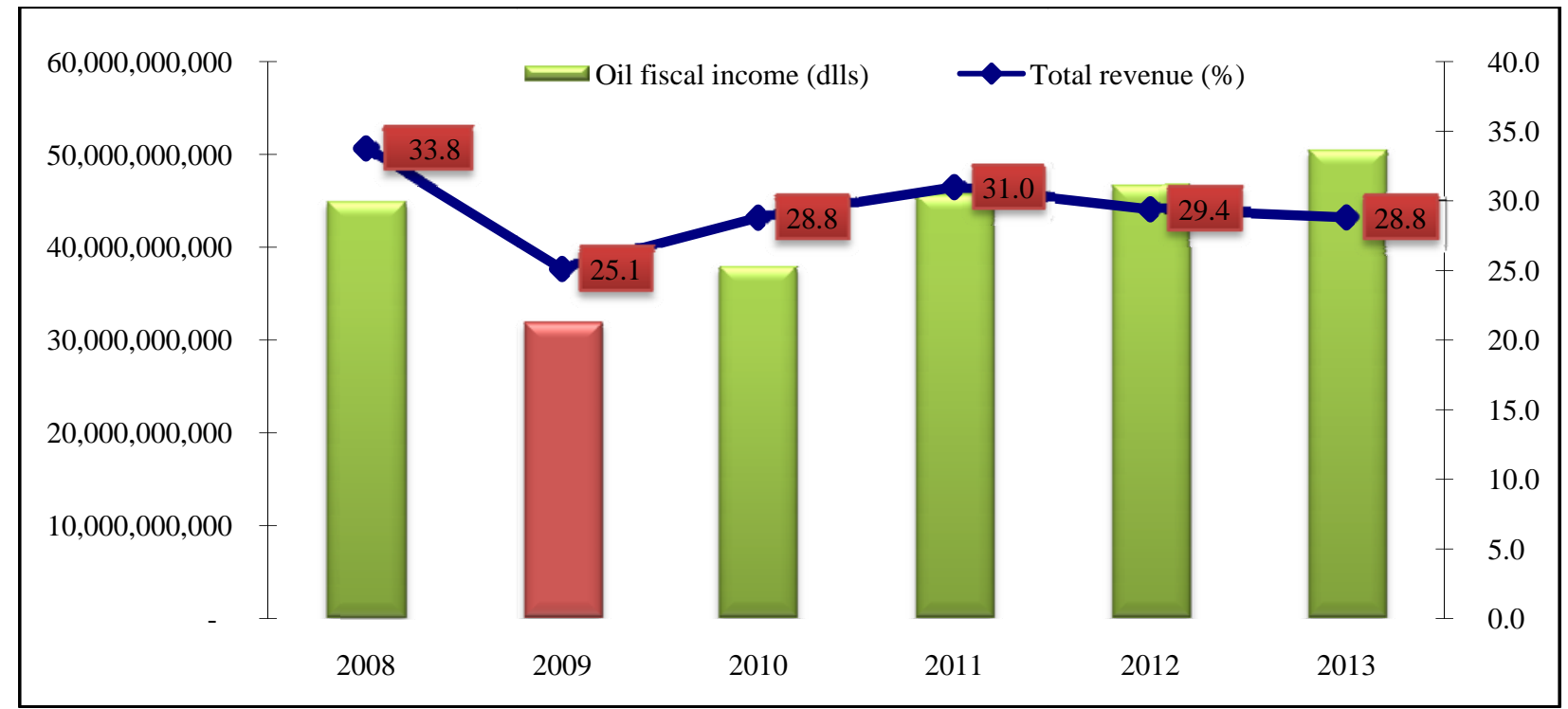

Figure 12. Oil fiscal income vs. percentage of total revenue. Source: prepared with data from INEGI.

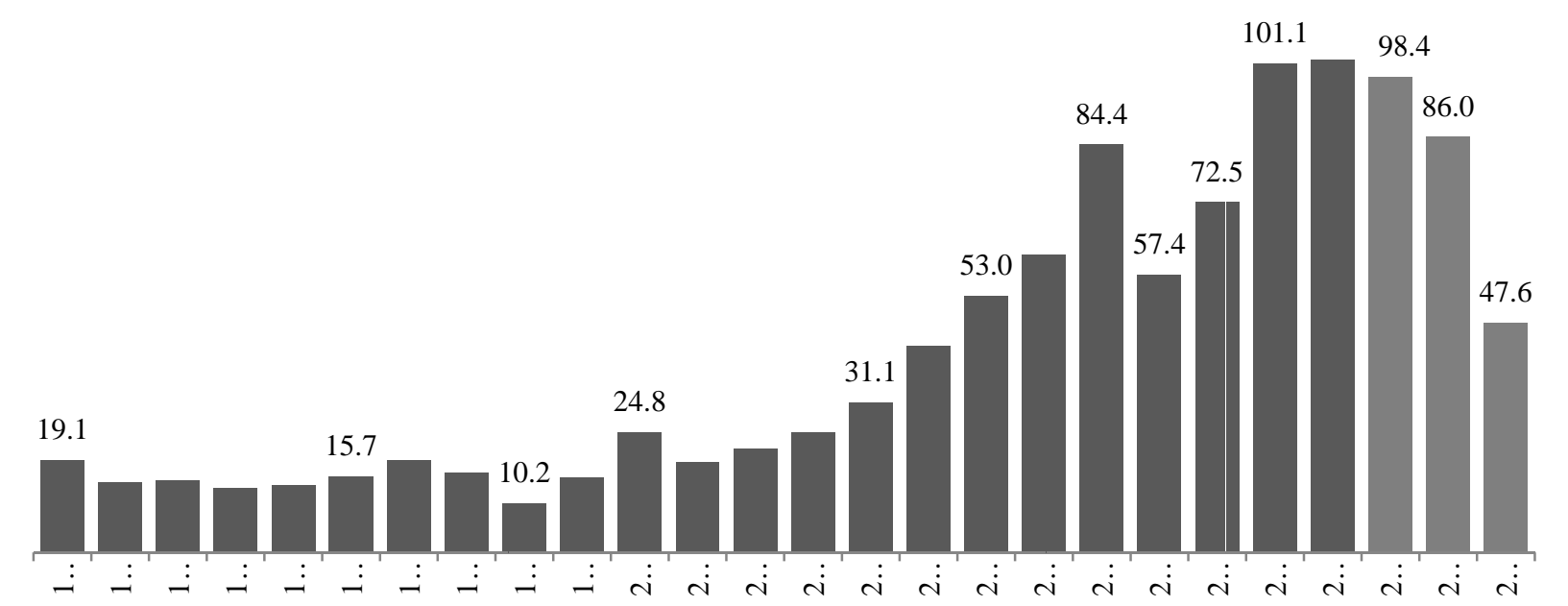

Figure 13. Price of the Mexican crude oil (dollars). Source: prepared with data from INEGI.

It is also important to mention that the Mexican economy has grown in recent years, with an average rate of $2.38 \%$, which has hurt to accelerate the development of the country and increase the standard of living of Mexicans, however, with approval and implementation of recent structural reforms, are expected to improve competitiveness (see Figure 14). 


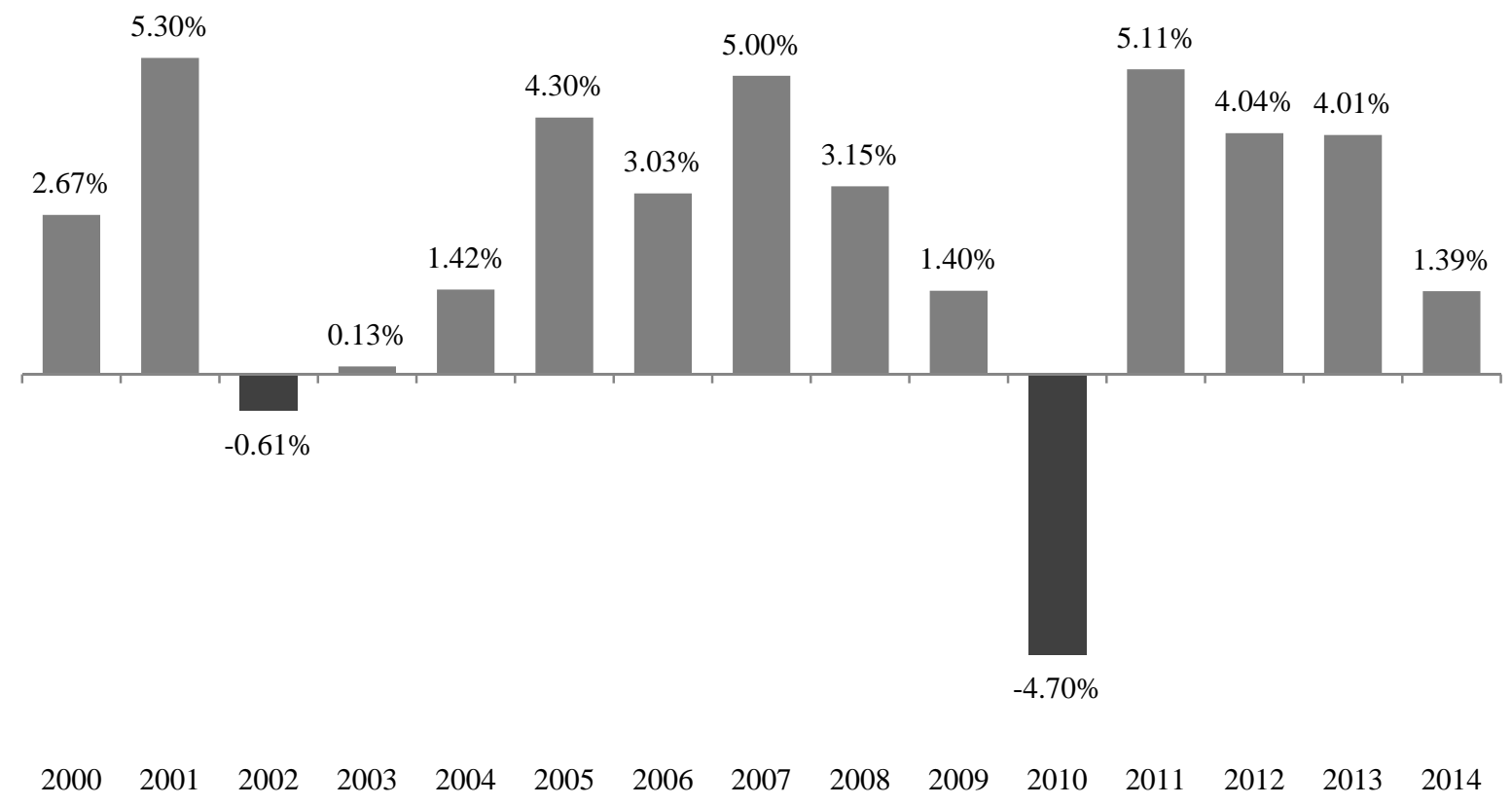

Figure 14. Annual average growth rate of the Mexican economy. Source: prepared with data from INEGI.

Besides the international financial crisis (subprime) and national factors such as H1N1 influenza, they weakened the majority of the world's economies, leaving sequels in the country, particularly in the states, having to borrow to overcome the weakness of tax revenue and not cut spending sharply in public works and services.

\section{Preventive Legal Framework of Sub-National Debt}

There are external players who observe the development of public finances, in addition to the Congress, Superior Audit, Ministry of Finance and State Governments are called risk rating agencies, who assume the power to "distinguish" by different scales; analyze the financial capacity of the issuer to meet its obligations. In this respect, the agencies help to mitigate information asymmetries and reduce costs (Banco de Mexico, 2015) that capitalists would have to analyze their own credit risks of each of your potential investments. But these are not infallible in the given grades or capture problems between "agent" and "principal" that might occur.

Returning to the structural weakness of the low revenue generation and excessive spending, incremental or poorly planned, in most of the states in Mexico, scarce tax resources conducive weakness in the generation of income, which leads to excessive dependence transfers coming from the federation, which are being regulated by the Law of Fiscal Coordination. So, states and municipalities are likely to acquire public debt, to support spending, primarily intended for public investment which could trigger problems with fiscal sustainability.

In this sense, the public debt is a matter of economic and political discussion among legislators, tax authorities, political parties, and civil society. Therefore, to analyze public policy in general or specific cases, for example, there are mentioned state laws to set limits in the following table (see Table 1).

Of all federal entities, there are only nine specify the limit to apply for and acquire public debt, establishing a maximum of up to the net amount of $10 \%$ of the total amount of their authorized budgets expenditures. The rest of the states listed in their respective laws of debt, which authorize local congress to hold the loan, leaving certainty the debt ceiling, there is also an ambiguity in the essential concepts. For example, 
what is meant by debt, productive public investment, among others. This makes that each local legislation has different criteria to authorize and limit the use of public debt, exacerbating the likelihood of corruption during the authorization process and expenditure of resources.

Table 1

Legal's Element of the Debt Limits

\begin{tabular}{|c|c|c|c|c|}
\hline State & Law & Article law & Preventive limit & $\begin{array}{l}\text { Specified limit } \\
\text { (1 “yes" } \\
\text { and } 0 \text { “no") }\end{array}$ \\
\hline Aguascalientes & Law on Public Debt "Aguascalientes" & Art. 20 & $\begin{array}{l}\text { Approved by the H. Legislature in program } \\
\text { funding in the financial period concerned }\end{array}$ & 0 \\
\hline Baja California & $\begin{array}{l}\text { Law on Public Debt of Baja } \\
\text { California and Municipalities } \\
\end{array}$ & Art. 5 & $\begin{array}{l}\text { Over } 10 \% \text { of the approved expenditure } \\
\text { budgets each year }\end{array}$ & 1 \\
\hline $\begin{array}{l}\text { Baja California } \\
\text { Sur }\end{array}$ & $\begin{array}{l}\text { Law on Public Debt Baja California } \\
\text { Sur }\end{array}$ & Art. 8 & $\begin{array}{l}\text { According to the terms of the expenditure } \\
\text { budget, and payment capacity of the } \\
\text { contracting public entity }\end{array}$ & 0 \\
\hline Campeche & $\begin{array}{l}\text { Law on Public Debt of Campeche and } \\
\text { Municipalities }\end{array}$ & Art. 9 & $\begin{array}{l}\text { Up to } 10 \% \text { of their revenue from the state or } \\
\text { municipality }\end{array}$ & 1 \\
\hline Coahuila & $\begin{array}{l}\text { Law on Public Debt of Coahuila De } \\
\text { Zaragoza }\end{array}$ & Art 12. & $\begin{array}{l}\text { Approved by the H. Legislature in program } \\
\text { funding in the financial period concerned }\end{array}$ & 0 \\
\hline Colima & Law on Public Debt of Colima & Art. 9 & $\begin{array}{l}\text { Approved by the H. Legislature in program } \\
\text { funding in the financial period concerned }\end{array}$ & 0 \\
\hline Chiapas & $\begin{array}{l}\text { Code of Public Finance for the State } \\
\text { of Chiapas }\end{array}$ & Art. 435 & $\begin{array}{l}\text { Does not exceed } 15 \% \text { of the aggregate } \\
\text { amount of their shares and income tax } \\
\text { own the current fiscal year }\end{array}$ & 1 \\
\hline Chihuahua & $\begin{array}{l}\text { Law on Public Debt of Chihuahua and } \\
\text { Municipalities }\end{array}$ & Art. 4 & $\begin{array}{l}\text { It must be provided annual borrowing } \\
\text { amounts and submit them to congress for } \\
\text { approval }\end{array}$ & 0 \\
\hline Durango & $\begin{array}{l}\text { Law on Public Debt of Durango and } \\
\text { Municipalities }\end{array}$ & Art. 12 & $\begin{array}{l}\text { The principal amount of the debt that does } \\
\text { not exceed } 12.5 \% \text { of revenue observed in the } \\
\text { previous fiscal year }\end{array}$ & 1 \\
\hline $\begin{array}{l}\text { Estado de } \\
\text { México }\end{array}$ & $\begin{array}{l}\text { Law on Public Debt of Estado De } \\
\text { México }\end{array}$ & Art. 9 & $\begin{array}{l}\text { Approved by the H. Legislature in program } \\
\text { funding laws and expense budget income of } \\
\text { the state and municipalities in the year } \\
\text { concerned }\end{array}$ & 0 \\
\hline Guanajuato & $\begin{array}{l}\text { Law on Public Debt of Guanajuato } \\
\text { and Municipalities }\end{array}$ & Art. 6 & $\begin{array}{l}\text { Up to the net amount of } 10 \% \text { of the total } \\
\text { amount of their budgets expenditures } \\
\text { authorized by congress }\end{array}$ & 1 \\
\hline Guerrero & Law on Public Debt of Guerrero & Art. 25 & $\begin{array}{l}\text { It is subject to the amounts and terms of debt } \\
\text { approved by the local congress }\end{array}$ & 0 \\
\hline Hidalgo & Law on Public Debt of Hidalgo & Art. 23 & $\begin{array}{l}\text { Authorized by congress annually in the State } \\
\text { Revenue Act and the laws of revenues of } \\
\text { municipalities, in the case of municipalities }\end{array}$ & 0 \\
\hline Jalisco & $\begin{array}{l}\text { Law on Public Debt of Jalisco and } \\
\text { Municipalities }\end{array}$ & Art. 5 & $\begin{array}{l}\text { Up to the net amount of } 10 \% \text { of the total } \\
\text { amount of their authorized budgets } \\
\text { expenditures }\end{array}$ & 1 \\
\hline Michoacán & Law on Public Debt of Michoacán & Art. 8 & $\begin{array}{l}\text { The amount corresponding to the payment of } \\
\text { debt service, in no case may exceed } 2.5 \% \text { of } \\
\text { the annual budget expenditures }\end{array}$ & 1 \\
\hline Morelos & Law on Public Debt of Morelos & Art. 23 & $\begin{array}{l}\text { Approved by congress in the financing } \\
\text { program in the year concerned }\end{array}$ & 0 \\
\hline Nayarit & Law on Public Debt of Nayarit & Art. 18 & $\begin{array}{l}\text { The approved for this purpose by the State } \\
\text { Legislature, as provided by this law }\end{array}$ & 0 \\
\hline Nuevo León & $\begin{array}{l}\text { Regulation of the Ministry of Finance } \\
\text { and State Treasury (Chapter Unit } \\
\text { Public Debt and Financing) }\end{array}$ & Art. 127 & $\begin{array}{l}\text { The amounts approved for that purpose by } \\
\text { the State Legislature, as provided by this law } \\
\text { (Act Financial Administration for the State } \\
\text { of Nuevo Leon) }\end{array}$ & 0 \\
\hline
\end{tabular}


Table 1 continued

\begin{tabular}{|c|c|c|c|c|}
\hline State & Law & Article law & Preventive limit & $\begin{array}{l}\text { Specified limit } \\
\text { (1 “yes” } \\
\text { and } 0 \text { “no”) } \\
\end{array}$ \\
\hline Oaxaca & Law on Public Debt of Oaxaca & Art. 6 & $\begin{array}{l}\text { Maximum amounts authorized by congress } \\
\text { for the debt to the regulated entities in } \\
\text { revenue laws (additional amounts } 10 \% \text { of } \\
\text { revenues prior authorization by natural } \\
\text { disasters) }\end{array}$ & 1 \\
\hline Puebla & Law on Public Debt of Puebla & Art. 14 & $\begin{array}{l}\text { The amounts authorized by congress in the } \\
\text { legislation concerned }\end{array}$ & 0 \\
\hline Querétaro & Law on Public Debt of Querétaro & Art. 4 & $\begin{array}{l}\text { Maximum amounts authorized by the } \mathrm{H} \text {. } \\
\text { Legislature under the law applicable income } \\
\text { as well as the exercise of indebtedness } \\
\text { amounts and concepts of unforeseen } \\
\text { authorized by law of income }\end{array}$ & 0 \\
\hline Quintana Roo & Law on Public Debt of Quintanta Roo & Art. 5 & $\begin{array}{l}\text { The Legislature may authorize public } \\
\text { entities to hire direct debt or contingent } \\
\text { amounts and at the times it may consider, if } \\
\text { they have the financial capacity to solve this }\end{array}$ & 0 \\
\hline San Luis Potosí & $\begin{array}{l}\text { Law on Public Debt of San Luis } \\
\text { Potosí }\end{array}$ & Art. 11 & $\begin{array}{l}\text { The total contract amount may not exceed } \\
20 \% \text { of their annual budgets approved on } \\
\text { income }\end{array}$ & 1 \\
\hline Sinaloa & Law on Public Debt of Sinaloa & Art. 23 & $\begin{array}{l}\text { Authorized by the State Congress annually } \\
\text { in the Law of Income and Expenditure } \\
\text { Budget of the State and the Laws of } \\
\text { Revenues of Municipalities } \\
\end{array}$ & 0 \\
\hline Sonora & Law on Public Debt of Sonora & Art. 6 & $\begin{array}{l}\text { Congress authorized the maximum amount } \\
\text { of net indebtedness of the state, parastatals } \\
\text { and municipalities and paramunicipales } \\
\text { entities, corresponding revenue laws }\end{array}$ & 0 \\
\hline Tabasco & $\begin{array}{l}\text { Law on Public Debt of Tabasco and } \\
\text { Municipalities }\end{array}$ & Art. 6 & $\begin{array}{l}\text { Congress authorized the maximum amount } \\
\text { of annual debt in the corresponding Revenue } \\
\text { Act of the State of Tabasco }\end{array}$ & 0 \\
\hline Tamaulipas & $\begin{array}{l}\text { Municipal and State Law of Public } \\
\text { Debt of Tamaulipas }\end{array}$ & Art. 17 & $\begin{array}{l}\text { Governmental entities may only obtain } \\
\text { credit with limiting net borrowing } \\
\text { authorized by the State Legislature }\end{array}$ & 0 \\
\hline Tlaxcala & $\begin{array}{l}\text { Public Debt Law for the State of } \\
\text { Tlaxcala and Municipalities }\end{array}$ & Art. 20 & $\begin{array}{l}\text { The celebration of loans or credits, be } \\
\text { subject to the amounts and terms of debt } \\
\text { approved by the State Congress }\end{array}$ & 0 \\
\hline Veracruz & $\begin{array}{l}\text { Financial Code for the State of } \\
\text { Veracruz }\end{array}$ & Art. 325 & $\begin{array}{l}\text { Approved by the H. Legislature in program } \\
\text { funding in the financial period concerned }\end{array}$ & 0 \\
\hline Yucatán & Law on Public Debt of Yucatan & Art. 10 & $\begin{array}{l}\text { Hiring debt by regulated entities shall be } \\
\text { subject to net debt amounts approved by } \\
\text { congress or the municipalities, as applicable, } \\
\text { and the provisions of this act }\end{array}$ & 0 \\
\hline Zacatecas & $\begin{array}{l}\text { Public Debt Law for the State and the } \\
\text { Municipalities of Zacatecas }\end{array}$ & Art. 9 & $\begin{array}{l}\text { The H. Legislature examine, discuss, and } \\
\text { approve the concepts, amounts, and items } \\
\text { relating to income from debt that should be } \\
\text { covered by the Laws of Income and } \\
\text { Expenditure Estimates Public Entities }\end{array}$ & 0 \\
\hline
\end{tabular}

Note. Source: prepared with sub national laws.

\section{Government Plans Anticrisis}

With respect to policies or plans to cushion the effects of the financial crisis in 2008-2009 state governments, they reacted fiscal and public investment cut. For example, about 28 sub-national governments took actions to improve economic activity and employment during the most severe part of the crisis, which 
amounted on average to $2.6 \%$ of GDP and more than 12,400 million dollars. Next, the main policies are described (see Figure 15).

\section{The Actions Undertaken by the States in Fiscal Policy Are Concentrated in Three Main Sections}
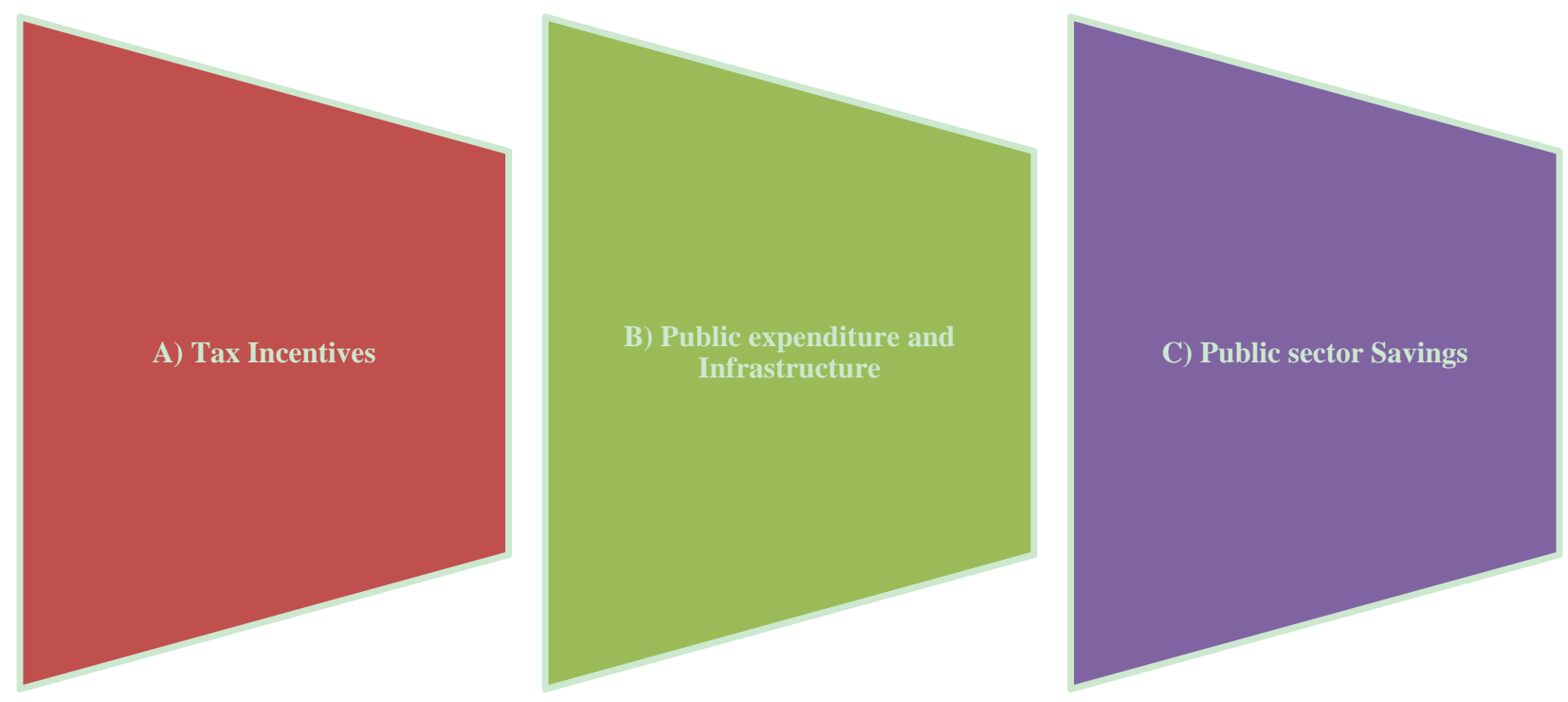

Figure 15. Actions by the states in fiscal policy.

Tax incentives. Nine sub-national governments orchestrated some incentive type, exemption, or reduction of the payroll tax rate for companies complied with their payments, to retain or create new jobs or start-ups that are installed in the state. Entities include this support are: Baja California, Mexico City, State of Mexico, Guerrero, Hidalgo, Morelos, Nuevo Leon, Oaxaca, Yucatan and Zacatecas.

In another sense, there are 15 entities, Baja California Sur, Coahuila, Chiapas, Chihuahua, Durango, Guerrero, Jalisco, Michoacán, Querétaro, Quintana Roo, Sinaloa, Sonora, Tabasco, Yucatan and Zacatecas, fiscal stimulus implemented in other taxes and duties as well as the freezing of rates in various public services, incentives, subsidies, guarantee funds, interest-free loans and preferential rates, and to waive fines and surcharges in the payment of taxes and duties.

Public expenditure and infrastructure. In almost all sub-national governments, all executed actions to improve the allocation and efficiency of public spending and higher percentage of spending on infrastructure, promotion of employment and social programs that allowed lessen the effects of the financial crisis in their states.

(1) Support for micro, small, and medium enterprises. In almost all of the governments, there were designed training programs, and preservation of the production plant, lines of credit, financing at preferential rates, economic promotion and local products abroad, among other measures;

(2) Public spending on social programs and services for vulnerable groups. Include study grants and training subsidies to public transport, freezing of rates of some public services, reducing the cost of paying some procedures and services, access to health services, micro-credit support, etc.;

(3) Public spending on infrastructure. Priority in the states in order to lessen the effects of the crisis in order to multiply the effects of the spending in this area and also the regions are in a better competitive position in the medium and long term, the expansion of infrastructure basic and productive in times of economic boom. 
Public sector savings. For the part of rationality and budgetary austerity, 17 states have established some kind of programs in order to improve the efficiency, effectiveness, and targeting of public spending. The main actions are the reduction of current expenditure without affecting the operation of strategic areas, cost containment, reduction of work places, as well as reducing salaries of top officials of the local government, in some cases.

In conclusion, these actions related to plans and programs of fiscal austerity spending favored investment and social programs over the administrative expenditure, but the effects were not as strong had to slow the fall in tax revenue, they had to resort to borrowing to shore up public budgets.

\section{Preliminary Lessons}

(1) Sub-national governments, as noted, with the crisis of 2009, do not have sufficient tools to overcome the crisis on its own, or have a legal and institutional framework that would ensure financial sustainability in the long term;

(2) Structural financial sustainability of sub-national government pressures, have their main obstacles: Public spending has grown faster than the rate of growth of local economies, as measured by the Gross Domestic Product of the State (GDPS), a high correlation between the incomes of the states and the international oil market, have no adequate source of income and fiscal policy strategies in sub-national governments to offset the volatility of oil prices; increasing and unsustainable pressures, for some cases, local pension system, with actuarial reserves which average around eight or nine years, with cases where they are exhausted;

(3) According to theoretical reasoning, excessive autonomy in debt carries risks, especially when chances of rescue by the central government occurs, and if the market does not impose discipline, then the government will try to borrow beyond recommended, leaving for the long term payments infrastructure and current expenditure of the day. It would be important to set limits on the autonomy of sub-national debt and strengthen control mechanisms, especially for public policies that governments wishing to implement future cannot see undermined by financial insolvency committed in the past;

(4) The worsening of the debt situation stemmed from a financial imbalance of the public entities which prevented public spending to fund projects under the plan of payments (suppliers and public works), which led to get resources through debt;

(5) The evidence suggests that when an austerity plan and budgetary rationality accompanied by a plan to strengthen their own income is implemented, as implemented, for example in the state of Jalisco in the incoming administration from 2013 to 2018, a decrease in pressure is generated financial and liabilities and investment prospects are improved;

(6) To improve the conditions of loans and financial discipline, it helps increase levels of investment and credit rating by the agencies and strengthens tax collection policies of states;

(7) The model of fiscal federalism should move toward a model with better prospects for local governments, the central government ceding some opportunities to implement tax powers with opportunities for economic return, such as a percentage of personal income taxes or sales retail;

(8) No booking funds sub-national governments, to mitigate the effects of a crisis; have not been created, or that may exist are not sufficiently anchored in good times, so at a low level oil prices debt of sub-national governments is increased. Although this variable has helped alleviate the crisis, this adjustment variable is 
limited for some sub-national governments to be exceeded as noted in the body of the paper;

(9) Public spending on sub-national governments maintained a strong momentum to the growth of spending on personal services bureaucracy fostered mainly by increasing annual negotiations with labor unions;

(10) The challenge of measuring corruption in the public sector properly for relating the loss of welfare of citizens in relation to the services provided by the government is pending. Therefore, it should be as a particular agenda for future analysis.

\section{References}

Alesina, A., Hausmann, R., Hommes, R., \& Stein, E. (1999). Budget institutions and fiscal performance in Latin America. Journal of Development Economics, 59(2), 253-273.

Alt, J. E., Lassen, D. D., \& Rose, S. (2006). The causes of fiscal transparency: Evidence from the American States. Retrieved from http://www.imf.org/external/np/res/seminars/2005/arc/pdf/alt.pdf

Banco de México. (2015). Rating agencies definitions. México, D.F.

Borensztein E., Levy, E., \& Panizza, U. (2007). Living with debt: How to limit the risks of sovereign finance. Economic and Social Progress in Latin America Report 2007. Interamerican Development Bank and David Rockefeller Center for Latin American Studies de la Universidad de Harvard, Washington, DC.

Buchanan, J., \& Wagner, R. (1977). Democracy in deficit: The political legacy of Lord Keynes (Vol. 8). New York: Academic Press.

Cespedes, L. (2011). Fiscal policy in times of crisis. Public spending lecture notes. Master in Public Policy, Department of Economics, University of Chile.

Chapman, J. I. (2008). State and local fiscal sustainability: The challenges. Public Administration Review, 68, S115-S131.

Coronado, J. (2009). Finance sustainability in subnational governments. Capacity Building Program Analysis and Debt Strategy for Highly Indebted Poor Countries. Publication No. 12, Debt Relief International, London, UK. Retrieved from http://www.hipc-cbp.org/

De la Cruz, R., Carlos, P., \& Caroline, P. (2010). Local alternative: Decentralization and economic development. Chapter Decentralization and Macroeconomic Control. Interamerican Development Bank, Washington, DC.

García, G. (2012). Fiscal rules for stability and sustainability (chapter). Tomorrow Fiscal Institutions. Institutions for People. Interamerican Development Bank, Washington, DC.

GASB (Government Accounting Standards Board). (2009). Project addressing fiscal sustainability to current technical agenda. Norwalk, Connecticut, Estados Unidos. Retrieved from http://www.gasb.org/

Hardin, G. (1968). The tragedy of commons. Science, New Series, 162(3859), 1243-1248.

Hernández, F. (2002). Financial risk management federal entities of Mexico: State contingency fund to fight macroeconomic risks. Management and Public Policy Review, 11(1). CIDE. México, D.F.

HR Ratings. (2015). Review of credit ratings following the new methodology for Mexican states. Public Finances. México, D.F.

Law-Act Federal Fiscal Coordination in México. (2015). México, D.F.

Moodys Investors Service. (2015). Elections risk unbudgeted increases in debt. Comment’s Sector. Web site Moodys México.

Musgrave, R. A., \& Musgrave, P. B. (1989). Public finance in theory and practice (5th ed.). New York: McGraw-Hill.

Rogoff, K., \& Sibert, A. (1988). Elections and macroeconomic policy cycles. Review of Economic Studies, 55(181), 1-16.

Rosen, H. (2005). Public finance (7th ed.). USA: McGraw-Hill Education.

Scartascini, C., Spiller, P., Stein, E., \& Tommasi, M. (2011). The political game in Latin America: How are public policies determined? Colombia: Mayol Editions.

Schuknecht, L. (1994). Political business cycles and expenditure policies in developing countries. IMF Working Papers 94/121. International Monetary Fund.

Secretary of Finance and Public Credit. (2011). Evaluation of the public debt policy. Federal Government from México, México, D.F.

Secretary of Finance and Public Credit. (2015). Timely statistics. Federal Government from México, México, D.F.

Stiglitz, J. (2000). Economics of the public sector (3rd ed.). USA: W. W. Norton \& Company.

Tabellini, G., \& Alesina, A. (1990). A positive theory of fiscal deficits and government debt. Departament of Economics, Harvard University. 
Valle, M., \& Galindo, A. (2010). Decentralization and subnational fiscal sustainability: The cases of Colombia and Peru. Country Department Andean Group, Inter-American Development Bank, Washington, DC.

Ward, R. B., \& Dadayan, L. (2009). State and local finance: Increasing focus on fiscal sustainability. The Journal of Federalism, 39(3), 455-475.

World Bank. (2010). Policymaking in the OECD: Ideas for Latin America. Unit Poverty Reduction and Economic Management Latin America and the Caribbean, World Bank Document, Washington, DC.

Zhao, B. (2012). The fiscal sustainability of state and local governments. Retrieved from http://www.taxadmin.org/fta/ meet/12rev_est/pres/zhao.pdf 